\title{
Antimicrobial effect of bothropstoxin-i in broilers
}

\section{Atividade antimicrobiana da bothropstoxin-i em frangos de corte}

\author{
Ana Carolina Portella Silveira ${ }^{1 *}$; Sarah Natalie Cirilo Gimenes ${ }^{2}$; Luiz Fernando \\ Barbaresco3; Camila Perdoncini Carvalho4; João Paulo Rodrigues Bueno5; Ednaldo \\ Carvalho Guimarães ${ }^{6}$; Paulo Fernando Alves de Freitas ; Mara Regina Bueno de \\ Mattos Nascimento; ${ }^{8}$ Robson Carlos Antunes ${ }^{8}$; Veridiana de Melo Rodrigues Ávila9
}

\section{Highlights}

BthTX-I may be useful in broilers without compromising performance.

BthTx-I decreases pathogenic bacteria in the intestinal microbiota of broilers.

BthTx-I does not cause muscle, liver or kidney damage.

\begin{abstract}
Bacterial resistance is a sanitary issue explained by indiscriminate use of nonprescription drugs, and antimicrobial use in food production for growth promotion. Bothropstoxin-I (BthTx-I) is a phospholipase $A_{2}$ $\left(\mathrm{PLA}_{2}\right)$ from Bothrops jararacussu venom, which has a known antimicrobial effect. The goal of this study was the unprecedented evaluation of in vivo antimicrobial activity of BthTx-I in broilers. Microbiological, biochemical, and histological parameters were determined using 84 21-day old broilers that were kept in cages with four birds each at a density of $625 \mathrm{~cm}^{2} / \mathrm{broiler}$. The experiment was randomized by three treatments with seven repetitions of four broilers each that lasted seven days. The treatments were: 1) bacitracin zinc diet; 2) PLA $A_{2}$-BthTx-I; 3) without additives. The data obtained from the studied variables was subjected to analysis of variance and an F-test at the $5 \%$ significance level. Averages of each variable in each treatment were compared by Tukey's test. Broiler bacterial cloacal counts showed that BthTx-I decreased the microbial population without reducing body weight, intestinal morphology, or liver or kidney histopathological damage. The toxin showed in vivo activity, being an alternative for better performance in the production of

1 Profa $\mathrm{Dr}^{\mathrm{a}}$, Instituto Federal do Triângulo Mineiro, IFTM, Uberaba, MG, Brasil. E-mail: anacarolinaportella@gmail.com

2 Bióloga, Instituto Butantan, São Paulo, SP, Brasil. E-mail: sarah_gi_menes@hotmail.com

3 Prof. Dr., Faculdade Pitágoras, Uberlândia, MG, Brasil. E-mail: Ifbarbaresco@hotmail.com

${ }^{4}$ Discente de Doutorado em Biologia Celular e Molecular Vegetal, Escola Superior de Agricultura Luiz de Queiroz, Universidade de São Paulo, ESALQ, USP, Piracicaba, SP, Brasil. E-mail: camila_perdoncini@hotmail.com

5 Prof. Dr., Centro Universitário do Triângulo, UNITRI, Uberlândia, MG, Brasil. E-mail: jprbueno@hotmail.com

6 Prof. Dr., Faculdade de Matemática, Universidade Federal de Uberlândia, UFU, Uberlândia, MG, Brasil. E-mail: ecg@ufu.br

7 Médico Veterinário da "Yes Nutrition", Uberaba, MG, Brasil. E-mail: pfafreitas@gmail.com

8 Profs. Drs., Faculdade de Medicina Veterinária, UFU, Uberlândia, MG, Brasil. E-mail: maran@ufu.br; robson.antunes@ ufu.br

9 Profa ${ }^{a} r^{a}$, Instituto de Genética e Bioquímica, UFU, Uberlândia, MG, Brasil. E-mail: vmravila@hotmail.com

* Author for correspondence
\end{abstract}

Received: Apr. 17, 2020 - Approved: Oct. 14, 2020 
broiler chickens, because it acted by decreasing the microbial load of potentially pathogenic bacteria in the intestinal microbiota of the birds and did not cause muscle, liver or kidney damage at the assessed dosage.

Key words: Biochemistry. Bothrops jararacussu. Nutrition. Phospholipase $\mathrm{A}_{2}$. Poultry. Snake venom.

\section{Resumo}

A resistência bacteriana é uma questão sanitária, explicada pelo uso indiscriminado de medicamentos sem receita médica e pelo uso de antimicrobianos na produção de alimentos para promover o crescimento. Bothropstoxin-I (BthTx-I) é uma fosfolipase $A_{2}\left(P L A_{2}\right)$ obtida do veneno da Bothrops jararacussu. $A$ $\mathrm{PLA}_{2}$ do veneno de cobra tem efeito antimicrobiano conhecido. Objetivou-se com este estudo avaliar sem precedentes a atividade antimicrobiana in vivo de BthTx-I em frangos de corte. Os parâmetros microbiológicos, bioquímicos e histológicos foram realizados em 84 frangos de corte com 21 dias de idade mantidos em gaiolas com quatro animais cada e densidade de $625 \mathrm{~cm}^{2} /$ frango. $O$ experimento foi dividido em três tratamentos com sete repetições de quatro frangos cada um, com duração de sete dias. Os tratamentos foram: 1) dieta com bacitracina de zinco; 2) PLA 2 -BthTx-I; 3) sem aditivos. Os dados obtidos das variáveis estudadas foram submetidos à análise de variância e teste $\mathrm{F}$ ao nível de significância de $5 \%$. As médias dos tratamentos em cada variável foram comparadas pelo teste de Tukey. A contagem cloacal bacteriana de frangos de corte mostrou que o BthTx-I diminuiu a população microbiana sem comprometer o peso corporal, a morfologia intestinal ou causar danos histopatológico no fígado e rins. Concluiu-se que a toxina apresentou atividade in vivo, sendo uma alternativa para um melhor desempenho na produção de frangos de corte, pois agiu diminuindo a carga microbiana de bactérias potencialmente patogênicas na microbiota intestinal das aves e não causou danos musculares, hepáticos ou renais na dosagem avaliada.

Palavras-chave: Avicultura. Bioquímica. Bothrops jararacussu. Fosfolipase $\mathrm{A}_{2}$. Nutrição. Veneno de cobra.

\section{Introduction}

Infection treatment is becoming increasingly difficult due to greater bacterial resistance against commonly used agents. In this context, several families of bacteria are responsible for human diseases around the world, such as Escherichia coli, Staphylococcus spp. and Salmonella spp. The Salmonella spp. is the group most commonly found and responsible for bacterial infection in humans (Moravej et al., 2018). For some years, antibiotic resistance has been recognized as a global health problem, and actually some studies show that bacterial resistance to antibiotic treatment is a problem in public health (Marshall \& Levy, 2011; Prestinaci, Pezzotti, \& Pantosti, 2015).
The cases of bacterial resistance to antibiotics have increased, and this is explained by indiscriminate or interrupted antibiotic use and in many developing countries the easy access to these drugs without prescription worsens the situation.

Itis worth mentioning that the Normative Instruction No 54 of December $17^{\text {th }}, 2018$ issued by the MAPA (2018) define measures for the appropriate use of antimicrobials indicated for animals whose derivatives and by-products are intended for human consumption, through the authotization and standardization of the use of veterinary medicines, and the fixation and controle of residual levels in order to prioritize food security. In turn, the Normative Instruction 
$N^{0} 1$ of January $13^{\text {th }}, 2020$ emphasizes that antimicrobials used in therapeutics should be avoided in the indication of food additives, performance enhancers or as preservatives for animal feed, bein prohibited the use of tylosin, lincomycin, and tiamulin (MAPA, 2020).

The exponential growth of the export Market in recent years shows thar companies seek to strictly follow the technical indications for the use of antimicrobials in feed (Fernandes, 2002). Yet, some studies have shown that antimicrobial used in food production for growth promotion and disease treatment is a potential contributor to worsening the problem of resistance (Marshall \& Levy, 2011). In particular, chicken meat production uses antimicrobials and chemotherapeutics in lower dosages to promote growth and/or feed efficiency and prevent and/or control diseases that affect the birds (Muaz, Riaz, Akhtar, Park, \& Ismail, 2018; Johnson et al., 2018). These antibiotics could be responsible for the increase in antibiotic resistance because this practice leaves antibiotic residues in chicken meat, which induces a cross-resistance to pathogenic bacteria in humans (Muaz et al. 2018). Therefore, is important to investigate alternative sources of treatment for bacterial infection and solve the problem of antibiotic resistance.

To find alternatives to address antibiotic resistance, snake venom may represent an alternative to traditional antibiotic use. They are complex mixtures of proteins and peptides, which account for $90-95 \%$ of their dry weight, but they also contain carbohydrates, lipids, nucleotides, amino acids, and inorganic components (O. H. P. Ramos \& Selistre de Araújo, 2006; Calvete, Juarez, \& Sanz, 2007; Talebi Mehrdar, Madani, Hajihosseini, \& Moradi Bidhendi, 2017). Some active substances have been isolated from snake venom and have shown interesting pharmacological effects, including antimicrobial activity; among these is phospholipase $A_{2}\left(P_{2} A_{2}\right.$ ) (Ferreira et al., 2013; Oliveira, Silva Cardoso, \& Franco, 2013; Soares et al., 2000).

In this context, bothropstoxin-I (BthTx-I), a Lys49 phospholipase $A_{2}$, isolated from Bothrops jararacussu, with molecular mass of $13.8 \mathrm{kDa}$ (Homsi-Brandeburgo, Queiroz, Santo, Rodrigues-Simioni, \& Giglio, 1988), and with in vitro lytic effects on the phospholipids of membranes of both bacterial groups Grampositive and Gram-negative (Lima et al., 2005; Valentin \& Lambeau, 2000), was used as a model as an alternative source for use in a broiler feed. In this work we investigated the properties of BthTx-I, in vivo and in vitro, as potential antibacterial agent in a broiler model according to its microbiological, biochemical and histological parameters.

\section{Materials and Methods}

\section{Bothropstoxin (BthTx-I) purification}

The BthTx-I was obtained from $B$. jararacussu snake venom. The snake venom was submitted to chromatography by $\mathrm{CM}$ Sepharose ion exchange with convex gradient, using $\mathrm{AMBIC} 0.05 \mathrm{M}$ and $0.5 \mathrm{M}$, according to Homsi-Brandeburgo et al. (1988).

\section{Bacterial culture}

Gram-positive bacterias Staphylococcus aureus (S. aureus) (ATCC 25923) and Enterococcus faecalis (E. faecalis) (ATCC 19433) and Gram-negative Escherichia coli (E. coli) (ATCC 25922) and Salmonella enterica 
subsp. enterica Enteritidis (S. Enteritidis) (ATCC 13076) were provided by the Reference Microorganisms Laboratory of the National Institute of Quality Control in Health from the Osvaldo Cruz Foundation located in Rio de Janeiro, Brazil. All strains were originally obtained from the American Type Culture collection (ATCC). The samples containing $S$. aureus, E. faecalis, S. Enteritidis, and E. coli were cultured in brain heart infusion (BHI) broth for $24 \mathrm{~h}$ in an incubator at $36^{\circ} \mathrm{C}$.

\section{Animals and experimental design}

This work was approved by the Ethics Committee for Animals (CEUA) of the Federal University of Uberlândia (UFU), protocol $n^{\circ}$ 075/12 and was carried out at an experimental broiler farm in a non-controlled environment at the Glory Farm, Federal University of Uberlândia, Minas Gerais.

For in vivo tests, eighty-four broilers were used for 21 days and maintained in cages with four birds each and a density of $625 \mathrm{~cm}^{2}$ I broiler. The experiment was randomized by three treatments with seven repetitions of four broilers each that lasted seven days. The treatment was divided randomly into the following groups with differentfeed preparation: Group A: addition of zinc bacitracin at $100 \mathrm{~g} /$ ton of feed; Group B: addition of BthTx-I at 20 $\mathrm{mg} / \mathrm{kg}$ of feed; Group C: feed with no addition of antimicrobial agent.

Feed formulations were made up according to the nutritional requirements proposed by Santos et al. (2013). The broilers were monitored until the 28th day for the observation of possible effects of the experiment conducted during the fourth week of breeding. Feed and water were made freely available throughout the entire trial. The weight gain (WG) and the daily weight gain (DWG) of the broilers were evaluated.. After the 28th day, 30 birds (10 from each treatment) were identified by rings and subjected to a 6 -h fasting period. They were subsequently weighed, desensitized by electronarcosis, slaughtered by bleeding the carotid artery, plucked and eviscerated. Slaughter followed environmental, handling, animal welfare, and sanitation standards.

\section{Evaluated parameters of in vitro model}

Antimicrobial activity and determination of minimum inhibitory concentration (MIC)

Bacteria used were cultivated in Mueller-Hinton medium with agitation at $37^{\circ} \mathrm{C}$. When the optical density at $600 \mathrm{~nm}$ reached a value of 1.0, each initial bacterial suspension was diluted (1:50 for Gram-negative and 1:100 for Gram-positive bacteria) in fresh Mueller-Hinton medium. Then 2-7 × $10^{5} \mathrm{CFUs}$ of each bacterial culture was incubated with sample in sterile 96-well plates and BthTx-I was used in different concentrations (200, $100,50,25,12.5,6.25,3.12$, and $1.56 \mu \mathrm{g} / \mathrm{mL}$ ). A sterile culture medium used as the control for absence of bacterial growth, and a sample containing bacterial suspension and sterile culture medium was used as the control indicating maximum growth. After incubation of $22 \mathrm{~h}$ at $37^{\circ} \mathrm{C}$, plates were analyzed at 595 $\mathrm{nm}$ in a 3550 UV microplate reader (Bio-Rad, Hercules, CA, USA).

All tests were conducted in duplicate, and the MIC was defined by the lowest concentration of antimicrobial that inhibited growth of a microorganism after overnight incubation. 


\section{Cell viability}

Viabilityassay used a murine endothelial cell line derived from a thymus endothelial cells (tEnd) obtained from ATCC and was cultured in RPMI-1640 medium containing 10\% (v/v) fetal bovine serum (FBS), $2 \mathrm{mM}$ L-glutamine, $2 \mathrm{mM}$ sodium pyruvate, $1 \mathrm{mM}$ non-essential amino acids, and $60 \mu \mathrm{g} / \mathrm{mL}$ gentamicin and incubated at $37^{\circ} \mathrm{C}$ and $5 \% \mathrm{CO}_{2}$.

The viability was evaluated using MTT (3-(4,5-dimethylthiazol-2-yl)-2,5diphenyltetrazolium bromide) assay. Cells were seeded at $5 \times 10^{4}$ cells per well in 96-well plates. After $24 \mathrm{~h}$, the medium was replaced with medium containing BthTX-I in different concentrations $(250,125,62.5,31.2,15.6$, or $7.8 \mu \mathrm{g} / \mathrm{mL}$ ), and control (phosphate buffered saline (PBS) in culture media). After 6 and 24 $h$, the cells were incubated with MTT for 3 $\mathrm{h}$ at $37{ }^{\circ} \mathrm{C}$. The formazan crystals resulting from the MTT reduction were dissolved by the addition PBS containing 10\% SDS and $0.01 \mathrm{M}$ hydrochloric acid. The absorbance was read on a multi-well scanning spectrophotometer (Multiskan Go, Thermo Scientific, Finland) at $570 \mathrm{~nm}$.

\section{Evaluated parameters of in vivo model}

\section{Microbiological parameters}

Samples were collected from cloacal swabs when the broilers were 21 and 28 days old and analyzed to evaluated counting of typical colonies E. coli, S. aureus, and Salmonella spp.

The cloacal swabs samples were diluted in $2 \%$ peptone water and re-diluted in tubes with $0.1 \%$ peptone water until they reached a concentration of $10^{-3} \mathrm{CFU} / \mathrm{mL}$. The pre-enrichment of the swabs was in buffered peptone water, which was incubated for 18-24 hat $37^{\circ} \mathrm{C}$. After the selective enrichment stage, $100 \mu \mathrm{L}$ of each dilution was plated, including Baird-Parker, SS (Salmonella-Shigella), and MacConkey agars, for the presumptive identification of $S$. aureus, Salmonella spp., and $E$. coli, respectively. The plates were incubated at $35^{\circ} \mathrm{C}$ for $24 \mathrm{~h}$ and later submitted for counting of typical colonies. Colony counts were transformed into $\log _{10}$ values for statistical analysis.

Morphometric analysis of small intestine mucosa

Immediately after slaughter, the abdominal cavity was opened and fragments of three segments of small intestine (duodenum, jejunum, and ileum) were collected and stored individually. Approximately $2 \mathrm{~cm}$ samples were taken from: duodenum (end of the duodenal loop); jejunum (from the distal duodenal loop to the Meckel's diverticulum) and ileum (anterior portion of the cecum).

The annular fragments were opened longitudinally and washed carefully with saline solution, preserving the villi. The extremities were stapled to white card to prevent closing of the luminal tissue and held in sodium phosphate at $\mathrm{pH} 7.4$ with $10 \%$ formaldehyde for fixation for $24 \mathrm{~h}$.

The material was analyzed; the procedures used were inclusion in paraffin, sectioning by microtome of approximately 5 $\mu \mathrm{m}$ and coloring in hematoxylin and eosin (HE). The images from the slides were captured at 40x magnification (Olympus BX 40 with an Olympus OLY 200 camera, Shinjuku, Japan) 
with an optical microscope attached to a computer via a Data Translation 3150 digitizer board and analyzed by software HL image 97 (Western Vision Software, Salt Lake City, UT, USA).

\section{Percentage of goblet cells per delimited area}

The quantitative analysis of goblet cells was made in a previously delimited region of the mucosa with integral villi of the duodenum, jejunum, and ileum segments of the small intestine in slides colored by Alcian blue and PAS (Periodic Acid Schiff). The images were captured and magnified 40X using an Olympus BX 40 optical microscope with an Olympus OLY 200 camera. For threshold segmentation or contact (Waldemarin, Beletti, \& Costa, 2004), binary images were formed and the percentage of black color was calculated in delimited areas that show the region of the globet cells by the program of analysis of $\mathrm{HL}$ Image 97 images (Western Vision Softwares).

\section{Serum biochemistry}

Bloods were kept at room temperature for $2 \mathrm{~h}$ for complete coagulation, centrifuged at $720 \mathrm{rpm}$ for $5 \mathrm{~min}$ and stored at $-20{ }^{\circ} \mathrm{C}$. Determination was made of the serum concentration of total proteins (biuret method); albumin (bromocresol green method); globulins; the albumin/globulin ratio; urea (UV kinetic method); creatinine (alkaline picrate method); uric acid (Trinder enzymatic method); alanine aminotransferase (ALT; UV-IFCC International Federation of Clinical Chemistry kinetic method); aspartate aminotransferase (AST; UV-IFCC kinetic method); and gamma glutamyl transferase (GGT; modified Szasz method).
Colorimetric tests used a ChemWell automatic multichannel analyzer (Awareness Technology Inc., Palm City, FL, United States) at a $37{ }^{\circ} \mathrm{C}$ using commercial kits (Labtest Diagnóstica $^{\circledR}$, Lagoa Santa, Minas Gerais, Brazil). The automatic analyzer was previously calibrated with Calibra $\mathrm{H}$ and gauged with Qualitrol 1H universal control serum.

\section{Liver and kidney histopathology}

Liver and kidney samples were collected, fixed in formaldehyde 10\%, and processed according to the following histological preparation: Briefly, the samples were dehydrated in alcohol, diaphanizated in xylene, included in histological paraffin, microtomed to a thickness of $5 \mu \mathrm{m}$, stained by $\mathrm{HE}$, and examined under an optical microscope (Olympus BX 40 with an Olympus OLY 200 camera, Shinjuku, Japan).

\section{Statistical analyses}

The experimental design was entirely randomized and composed of three treatments and seven repetitions, using a total of 84 broilers ( 28 broilers per portion). The data obtained from the studied variables was subjected to analysis of variance and an F-test at the 5\% significance level. Averages of treatments in each variable were compared by Tukey's test. When there was no normality and/or homogeneity of variances required for ANOVA, Kruskal-Wallis and/or Wilcoxon nonparametric tests were used for comparisons at $5 \%$ significance. Normality was tested with the Anderson-Darling Test and variance homogeneity with Bartlett's Test. The SISVAR statistical program was used for all analyses. 


\section{Results and Discussion}

The weight gain (WG) and the daily weight gain (DWG) of the broilers were evaluated from 21-28 days old; there were no differences between treatments: A) WG $=837.1 \mathrm{~g}$ and DWG $=120 \mathrm{~g} ; \mathrm{B}) \mathrm{WG}=817.8 \mathrm{~g}$ and $\mathrm{DWG}=117 \mathrm{~g} ; \mathrm{C})$ $W G=793.3 \mathrm{~g}$ and $\mathrm{DWG}=113 \mathrm{~g}$.

\section{Antimicrobial activity in vitro}

The bacterial group tested in this work is already found in the normal microbiota of broilers (Bitterncourt et al., 2011), and some strains have been used for a variety of beneficial purposes in broiler nutrition, including the production of probiotics as dietary supplements. Bacteria with probiotic effect belong to Enterococcus and are resistant to the surrounding conditions with high viability (Nunes et al., 2012). Other bacterial species have been described to have beneficial effects on broiler performance, such as modulation of intestinal microbiota and pathogen inhibition, immunomodulation and intestinal histological changes, and they improve the sensory characteristics of broiler meat and promote the meat quality of broilers (L. S. N. Ramos, Lopes, Silva, Silva, \& Ribeiro, 2011).

Therefore, the bactericidal action in vitro of BthTX-I was expressed as percentage of growth inhibition (Figure 1), and the MIC values were calculated as $50 \mu \mathrm{g} / \mathrm{mL}$ for $S$. aureus, 6.25 $\mu \mathrm{g} / \mathrm{mL}$ for $S$. Enteritidis and $100 \mu \mathrm{g} / \mathrm{mL}$ for $E$. coli. The results for $E$. faecalis bacteria were not included because any concentration of any sample tested was able to inhibit its growth.

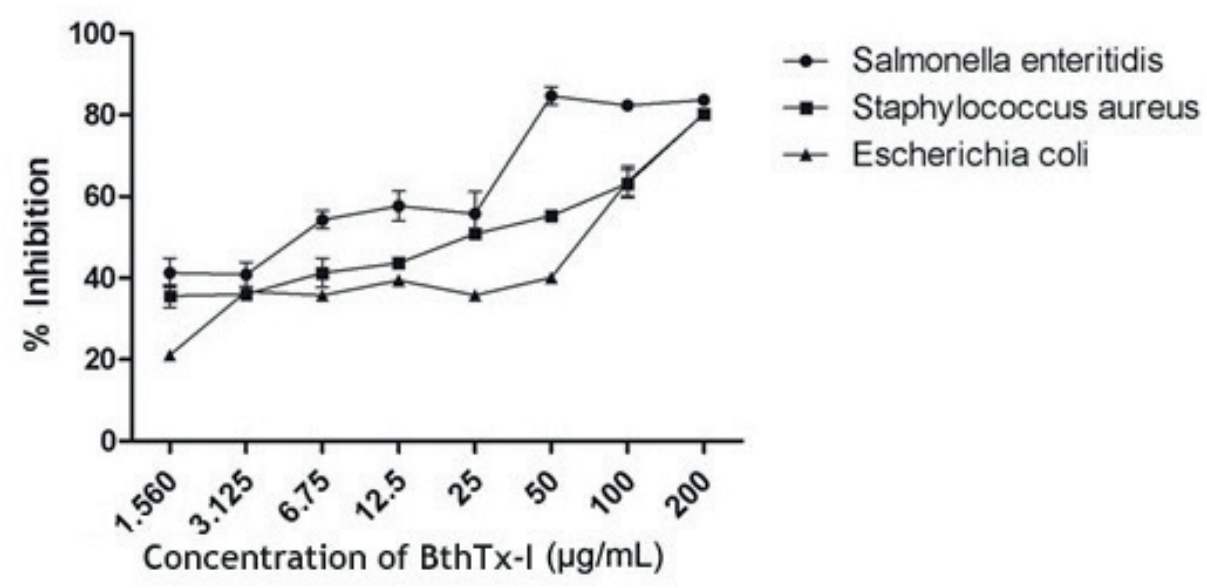

Figure 1. Broth microdilution antibacterial assay of BthTx-I. Staphylococcus aureus; Salmonella Enteritidis; Escherichia coli. 


\section{Cytotoxic activity}

The cytotoxic activity of BthTx-I after 6 $\mathrm{h}$ caused a significant decrease in endothelial cell viability compared with the control at 250 and $125 \mu \mathrm{g} / \mathrm{mL}$, besides morphological damage to cells, such as membrane rupture and cellular lysis. After $24 \mathrm{~h}$, the 31.2 and 62.5 $\mu \mathrm{g} / \mathrm{mL}$ concentrations also caused significant cellular damage (Figure 2). The lowest cytotoxic concentration of BthTx-I was $31.2 \mu \mathrm{g} / \mathrm{mL}$, and we used this lowest concentration as a parameter to calculate of BthTx-I concentration to be used for in vivo assays.

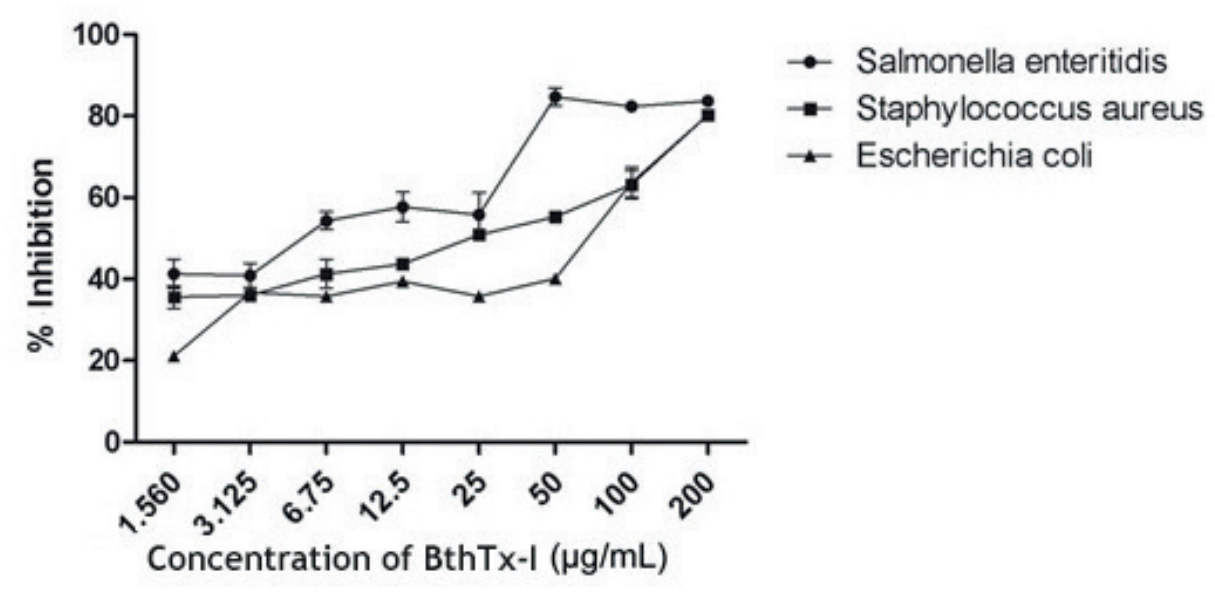

Figure 2. Cytotoxicity effects of BthTx-I toward tEnd cells at $6 \mathrm{~h}$ and at 24 $\mathrm{h}$ at different concentrations $(250,125,62.5,31.25,15.6,7.8,3.9 \mu \mathrm{g} / \mathrm{mL})$.

\section{Antimicrobial activity in vivo}

\section{Intestinal histomorphometry}

The intestinal villi are responsible for increasing the organ's internal surface for digestion and intestinal absorption, and their height varies throughout the entire intestine. In the duodenum, the villi are longer and digiform; in the jejunum and ileum they can be lameliform, with a foliaceus aspect. They are lined by simple epithelia, comprising three cell types: goblet cells, enterocytes and enteroendocrine cells, which are responsible for defense, digestion and absorption; regulation of those processes; and proliferation and differentiation of those cell types, respectively (Uni, Ganot, \& Sklan,
1998; Furlan, Carvalho, Malheiros, \& Macari, 2001).

Therefore, to investigate the toxic effect of BthTx-I treatment on intestinal cells, we analyzed the histomorphometry of intestinal cells. It is known that the capacity for nutrient absorption is proportional to the mucosal area available for absorption, and in broilers the area responsible for absorption is the duodenum (Furlan et al., 2001). Therefore, the mucosal area was calculated in the three small intestine segments of the broilers after treatment and evaluated in all groups (Table 1); the data showed that the BthTx-I treatment did not cause intestinal damage. 
Table 1

Area of average mucosa $\left(\mu \mathrm{m}^{2}\right)$ of the duodenum, jejunum, and ileum of broilers at 28 days subjected to different treatments

\begin{tabular}{lccc} 
& \multicolumn{3}{c}{ Treatment $^{1}$} \\
\cline { 2 - 4 } Segments & $\mathrm{A}$ & $\mathrm{B}$ & $\mathrm{C}$ \\
Duodenum & $16.75 \mathrm{a}$ & $18.37 \mathrm{a}$ & $16.89 \mathrm{a}$ \\
Jejunum & $14.90 \mathrm{a}$ & $15.91 \mathrm{a}$ & $14.71 \mathrm{a}$ \\
lleum & $11.70 \mathrm{a}$ & $11.87 \mathrm{a}$ & $13.46 \mathrm{a}$
\end{tabular}

Means followed by different letters on the row differ from each other by the Tukey test $(P>0.05) .{ }^{1} A$ : with antibiotics; $B$ : with BthTx-l; C: control.

\section{Percentage of goblet cells}

The other measure used to describe the impact of BthTx-I on intestinal cells was the goblet cell count. These cells are responsible for producing mucus, a secretion composed mainly of water, electrolytes and a mix of several glycoproteins, whose functions include lubricating the intestinal lining, providing protection against abrasive agents in the diet and pathogenic agents, and participating in nutrient absorption (Pickler et al., 2012).
Mucus is important in participating in the nonspecific immune response, and a large number of goblet cells indicates that some type of sanitation challenge may exist that requires an increase in mucus production. On the other hand, mucus in large amounts can harm broiler health because it increases intestinal traffic and reduces nutrient absorption (Pickler et al., 2012), although this was not observed in this experiment (Table 2).

\section{Table 2}

Percentage of goblet cells in the duodenum area bounded by segments of the duodenum, jejunum, and ileum of the small intestine of broilers subjected to different treatments

\begin{tabular}{lccc} 
& \multicolumn{3}{c}{ Treatment $^{1}$} \\
\cline { 2 - 4 } Segments & $\mathrm{A}$ & $\mathrm{B}$ & $\mathrm{C}$ \\
Duodenum & $0.45 \mathrm{aA}$ & $0.69 \mathrm{aA}$ & $0.47 \mathrm{aA}$ \\
Jejunum & $0.74 \mathrm{aA}$ & $1.08 \mathrm{aA}$ & $1.13 \mathrm{aA}$ \\
lleum & $3.37 \mathrm{aA}$ & $2.68 \mathrm{aA}$ & $3.11 \mathrm{aA}$
\end{tabular}

Means followed by different lowercase letters in the row and different uppercase letters in the column differ by the Tukey test $(P>0.05) .{ }^{1} \mathrm{~A}$ : with antibiotics; $B$ : with BthTx-I; C: control. 
Our study showed that there were no differences in the production of goblet cells between treatments. However, in all of them the ileum showed a higher number of those cells compared to the other segments (Table 2). These data have been described by other studies, which showed the number of goblet cells determines mucus production in the small intestine, being less abundant in the duodenum and increased in the ileum (Bogucka et al., 2017; Cheng et al., 2014).

\section{Serum biochemistry}

To evaluate the effect of BthTx-I on serum composition, we analyzed the biochemistry parameters in broiler serum. These tests provided important information related to the physiological, clinical, metabolic, and productive state of the birds. The protein metabolism was evaluated through analyses of total proteins, albumin, globulins, uric acid, and urea level. Creatinine and ALT, AST and GGT enzymes were examined for evaluation of renal and hepatic function, respectively (Table 3).

Only the creatinine level showed a significant statistical difference in all analyses. The treatment with BthTx-I resulted in a higher value compared to treatment $\mathrm{C}$ (control group); however, this was within the normal reference range of $0.25-0.41 \mathrm{mg} / \mathrm{dL}$ (Borsa, Kohayagawa, Boretti, Saito, \& Kuibida, 2006). Creatinine is present in low plasma concentration in broilers and its changes in concentration are not related to renal dysfunction, mainly when uric acid values remain unchanged. For any healthy population, normality values are within the average \pm standard deviation; $5 \%$ of the population shows values outside the standard due solely to individual characteristics (Ross, Christie, Halliday, \& Jones, 1977).

Then, we showed that there was no statistically significant difference in albumin/ globulin ratio between the treatments, indicating that the inclusion of BthTx-I in feed did not cause changes in the metabolism of protein and enzyme in broilers when compared to the other treatments. Some works have shown that the albumin/globulin ratio in broilers is a highly significant clinical indicator: when the albumin/globulin ratio changes, there are infections and increases in immunoglobulin concentration (Bacila, 2003; Kaneko, Harvey, \& Bruss, 2008). In addition, our data showed that BthTx-I did not induce an inflammatory response in any of groups. 


\section{Table 3}

Mean values and standard deviation of serum biochemical parameters of broilers at 28 days of age undergoing different treatments

\begin{tabular}{|c|c|c|c|}
\hline \multirow{2}{*}{ Variables } & \multicolumn{3}{|c|}{ Treatment $^{1}$} \\
\hline & A & B & C \\
\hline Uric acid (mg dL-1) & 5.82a 2.29 & 5.42a 1.82 & 4.59a 1.51 \\
\hline Urea (mg dL-1) & 7.49a 3.86 & 6.09a 3.12 & 7.33a 2.85 \\
\hline Creatinine $\left(\mathrm{mg} \mathrm{dL}^{-1}\right)$ & 0.38 a 0.14 & $0.41 a 0.1$ & $0.28 a 0.05$ \\
\hline Albumin $\left(\mathrm{g} \mathrm{L}^{-1}\right)$ & $1.20 \mathrm{a} 0.23$ & $1.20 a 0.25$ & $1.15 a 0.15$ \\
\hline Globulin (g L ${ }^{-1}$ ) & 2.79a 0.34 & 2.59a 0.51 & $2.48 a 0.27$ \\
\hline Total proteins $\left(\mathrm{g} \mathrm{L}^{-1}\right)$ & 4.00a 0.30 & 3.78a 0.45 & $3.67 a 0.34$ \\
\hline Alb/Glob $\left(\mathrm{g} \mathrm{L}^{-1}\right)$ & $0.44 a 0.12$ & $0.48 a 0.18$ & $0.48 a 0.09$ \\
\hline GGT (U L-1) & 22.07a 10.94 & 25.96a 11.22 & 19.45a 3.33 \\
\hline AST $\left(U L^{-1}\right)$ & 241.27a 53.01 & 217.63a 18.22 & 232.62a 64.00 \\
\hline $\operatorname{ALT}\left(\mathrm{UL}^{-1}\right)$ & 46.60a 33.48 & 38.81a 26.82 & 30.12a 20.08 \\
\hline
\end{tabular}

Means followed by different letters on the row differ from each other by the Tukey test $(P>0.05) .{ }^{1} A$ : with antibiotics; $B$ : with BthTx-l; C: control.

\section{Liver and kidney histopathology}

In agreement with serum biochemistry results, our data showed that there were no renal or hepatic lesions in any broilers evaluated in this study at a histopathological level.

\section{Microbiological evaluations}

The bacteria S. aureus, E. coli, and Salmonella spp. were evaluated at 21 and 28 days of age, before and after introduction of the antibiotics and BthTx-l in their feed. The value of $400 \times 10^{3} \mathrm{CFU} / \mathrm{mL}$ was considered as the basis for statistical calculations in plates considered uncountable. The microbiological results showed the presence of $E$. coli and S. aureus in all cloacal swabs at the beginning to treatment, as it is known that they are microorganisms considered normal in the microbiota of broilers (Table 4). Salmonella spp. was not detected at any time in the cloacal swabs; these bacteria are not an integral part of the healthy intestinal microbiota of broilers, and according to Silva \& Duarte (2002) there are no species adapted to broilers.

The bacterial counts from cloacal swabs showed significant reductions in S. aureus and E. coli after 7 days of treatment of broilers in the $B$ group (treated with BthTX-I PLA $A_{2}$ ); this data suggest that BthTx-I mixed in the feed was capable of acting on the intestine and showing antimicrobial activity, as previously described in the in vitro test (Figure 1).

The antimicrobial action of $\mathrm{PLA}_{2}$ is not completely elucidated; however, it is known that catalytic function is not necessary for its pharmacological effect, as studies have shown

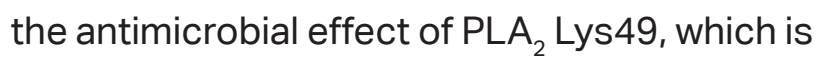

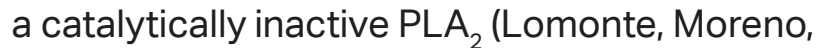
Tarkowski, Hanson, \& Maccarana, 1994; Paramo et al., 1998). Some authors have demonstrated 
a relationship between the $\mathrm{C}$-terminal region of $\mathrm{PLA}_{2}$ Lys 49 and its biological activities, such as cytotoxic and antimicrobial activities (Soares et al., 2001; Lomonte, Angulo, \& Santamaria, 2003). According to Segrest, De Loof, Dohlman,
Brouillette, \& Anantharamaiah (1990), protein groups with hydrophobic feature and positive charge could interact with and permeate biological lipid membranes, thus inducing the cytotoxic activities.

\section{Table 4}

Counts of Escherichia coli and Staphylococcus aureus $\left(\log _{10}\right)$ in the cloacal swabs of 21- and 28-dayold broilers submitted to different treatments

\section{Cloacal swabs}

\begin{tabular}{lcccc} 
& \multicolumn{2}{c}{21 days } & \multicolumn{2}{c}{28 days } \\
Treatment $^{1}$ & E. coli & S. aureus & E. coli & S. aureus \\
A & $5.0 \mathrm{aA}$ & - & $4.3 \mathrm{aA}$ & - \\
B & $4.6 \mathrm{aA}$ & $5.6 \mathrm{aA}$ & $0.0 \mathrm{bB}$ & $0.0 \mathrm{bB}$ \\
C & $5.1 \mathrm{aA}$ & $5.6 \mathrm{aA}$ & $4.4 \mathrm{aA}$ & $5.6 \mathrm{aA}$
\end{tabular}

Means followed by different lowercase letters in the row and different uppercase letters in the column differ by the Tukey test $(P>0.05)$ between the first culture (21 days) and the second culture (28 days). ${ }^{1}$ A: with antibiotics; B: with BthTx-l; C: control.

Thus, the treatment of broiler feed with

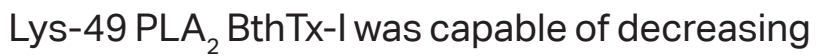
the microbial level in an in vivo model of potentially pathogenic bacteria in the intestinal microbiota and did not cause muscular, hepatic, or renal damage or lesions at the evaluated dosage. These data showed that BthTx-I could act as performance enhancer in chicken meat production and as a good alternative to the use of antibiotics, since, as a protein, BthTx-I leaves no residue in the chicken meat.

\section{Conclusions}

The toxin showed in vivo activity, being an alternative for better performance in the production of broiler chickens, because it acted by decreasing the microbial load of potentially pathogenic bacteria in the intestinal microbiota of broilers and did not cause muscle, liver or kidney damage at the assessed dosage.

\section{Acknowledgments}

The authors are grateful for the financial support from CAPES; Fundação de Amparo à Pesquisa do Estado de Minas Gerais (FAPEMIG); Fundação de Amparo à Pesquisa do Estado de São Paulo (FAPESP); Conselho Nacional de Desenvolvimento Científico e Tecnológico (CNPq), and Universidade Federal de Uberlândia (UFU). 


\section{References}

Bacila, M. (2003). Bioquímica Veterinária. São Paulo, SP : Robe.

Bitterncourt, L. C., Silva, C. C., Garcia, P. D. S. R., Donato, D. C. Z., Albuquerque, R., \& Araújo, L. F. (2011). Influence of a probiotic on broiler performance. Revista Brasileira de Zootecnia, 40(12), 2739-2743. doi: 10.1590/S1516-35982011001200018

Bogucka, J., Dankowiakowska, A., EilminowskaWenda, G., Sobolewska, A., Jankowski, J., Szpinda M., \& Bednarczyk, M. (2017). Annals of Animal Science, 17(1), 179-195. doi: 10.1515/aoas-2016-0048

Borsa, A., Kohayagawa, A., Boretti, L. P., Saito, M. E., \& Kuibida, K. (2006). Níveis séricos de enzimas de função hepática em frangos de corte de criação industrial clinicamente saudáveis. Arquivo Brasileiro de Medicina Veterinária e Zootecnia, $58(4)$, 675-677. doi: 10.1590/S010209352006000400035

Calvete, J. J., Juarez, P., \& Sanz, L. (2007). Snake venomics. Strategy and applications. Journal of Mass Spectrometry, 42(11), 1405-1414. doi: 10.1002/jms.1242

Cheng, G., Hao, H., Xie, S., Wang, X., Dai, M., Huang, L., \& Yuan, Z. (2014). Antibiotic alternatives: the substitution of antibiotics in animal husbandry? Frontiers in Microbiology, 5(art.217), 1-15. doi: 10. 3389/fmicb.2014.00217

Fernandes, P. (2002). Como produzir carne de aves e suínos sem o uso de antibióticos promotores de crescimento nas dietas. Anais do Congresso de Agribusiness, Rio de Janeiro, RJ, Brasil, 4. Recuperado de https://www.sna.agr.br/agribusiness/wpcontent/uploads/4C_PauloFernandes.pdf

Ferreira, F. B., Gomes, M. S. R., Souza, D. L. N., Gimenes, S. N. C., Castanheira, L. E., Borges,
M. H.,... Rodrigues, V. M. (2013) Molecular cloning and pharmacological properties of an acidic PLA2 from Bothrops pauloensis snake venom. Toxins, 5(12), 2403-2419. doi: 10.3390/toxins5122403

Furlan, R. L., Carvalho, N. C., Malheiros, E. B., \& Macari, M. (2001). Efeito da restrição alimentar inicial e da temperatura ambiente sobre o desenvolvimento de vísceras e ganho compensatório em frangos de corte. Arquivo Brasileiro de Medicina Veterinária e Zootecnia, 53(4), 1-7. doi: 10.1590/S0102-09352001000400019

Homsi-Brandeburgo, M. I., Queiroz, L. S., Santo, H., Neto, Rodrigues-Simioni, L., \& Giglio, J. R. (1988). Fractionation of Bothrops jararacussu snake venom: partial chemical characterization and biological activity of bothropstoxin. Toxicon : Official Journal of the International Society of Toxinology, 26(7), 615-627. doi: 10.1016/0041-0101 (88) $90244-9$

Johnson, T. J., Youmans, B. P., Noll, S., Cardona, C., Evans, N. P., Karnezos, T. P.,... Lee, C.W. (2018). A consistent and predictable commercial broiler chicken bacterial microbiota in antibiotic-free production displays strong correlations with performance. Applied and Environmental Microbiology, 84(12), e00362-18. doi: 10.1128/AEM.00362-18

Kaneko, J. J., Harvey, J. W., \& Bruss, M. L (2008). Clinical biochemistry of domestic animal (6nd ed.). San Diego: Academic.

Lima, D. C., Abreu, P. A., Freitas, C. C., Santos, D. O., Borges, R. O., Santos, T. C.,... Castro, H. C. (2005). Snake venom: any clue for antibiotics and CAM? Evidence-Based Complementary and Alternative Medicine, 2(1), 39-47. doi: 10.1093/ecam/neh063

Lomonte, B., Angulo, Y., \& Santamaria, C. (2003). Comparative study of synthetic peptides 
corresponding to region $115-129$ in Lys49 myotoxic phospholipases A2 from snake venoms. Toxicon: Official Journal of the International Society of Toxinology, 42(3), 307-312. doi: 10.1016/s0041-0101 (03)00149-1

Lomonte, B., Moreno, E., Tarkowski, A., Hanson, L. A., \& Maccarana, M. (1994). Neutralizing interaction between heparins and myotoxin II, a lysine 49 phospholipase A2 from Bothrops asper snake venom. Identification of a heparin-binding and cytolytic toxin region by the use of synthetic peptides and molecular modeling. The Journal of Biological Chemistry, 269(47), 29867-29873.

Ministério da Agricultura, Pecuária e Abastecimento 2020. Instrução Normativa $n^{\circ} 1$, de 13 de janeiro de 2020. Recuperado de https://www.in.gov.br/en/ web/dou/-/instrucao-normativa-n-1-de13-de-janeiro-de-2020-239402385

Ministério da Agricultura, Pecuária e Abastecimento 2018. Instrução Normativa $\mathrm{n}^{\circ}$ 54, de 17 de dezembro de 2018. Recuperado de https://www. in.gov.br/materia/-/asset_publisher/ Kujrw0TZC2Mb/content/id/57733217/ d o 1 - $2019-01-03$ - in strucaonormativa-n-54-de-17-de-dezembrode-2018-57733055

Marshall, B. M., \& Levy, S. B. (2011). Food animals and antimicrobials: impacts on human health. Clinical Microbiology Reviews, 24(4), 718-733. doi: 10.1128/CMR.0000211

Moravej, H., Moravej, Z., Yazdanparast, M., Heiat, M., Mirhosseini, A., Moghaddam, M. M., \& Mirnejad R. (2018). Antimicrobial peptides: features, action, and their resistance mechanisms in bacteria. Microbial Drug Resistance, 24(6), 747-767. doi: 10.1089/ mdr.2017.0392
Muaz, K., Riaz, M., Akhtar, S., Park, S., \& Ismail, A. (2018). Antibiotic residues in chicken meat: global prevalence, threats, and decontamination strategies: a review. Journal of Food Protection, 81(4), 619627. doi: 10.4315/0362-028X.JFP-17086

Nunes, R. V., Scherer, C., Pozza, P. C., Eyng, C., Bruno, L. D. G., \& Vieites, F. M. (2012). Use of probiotics to replace antibiotics for broilers. Revista Brasileira de Zootecnia, 41(10), 2219-2224. doi: 10.1590/ S151635982012001000012

Oliveira, N. G., Jr., Silva Cardoso, M. H., \& Franco, O. L. (2013). Snake venoms: attractive antimicrobial proteinaceous compounds for therapeutic purposes. Cellular and Molecular Life Sciences, 70(24), 46454658. doi: 10.1007/s00018-013-1345-x

Paramo, L., Lomonte, B., Pizarro-Cerdá, J., Bengoechea, J. A., Gorvel, J. P., \& Moreno, E. (1998). Bactericidal activity of Lys49 and Asp49 myotoxic phospholipases A2 from Bothrops asper snake venom-synthetic Lys49 myotoxin II-(115-129)peptide identifies its bactericidal region. European Journal of Biochemistry, 253(2), 452-461. doi: 10.1046/j.14321327.1998.2530452.x

Pickler, L., Hayashi, R. M., Lourenço, M. C., Miglino, L. B., Caron, L. F., Beirão, B. C. B.,... Santin, E. (2012). Avaliação microbiológica, histológica e imunológica de frangos de corte desafiados com Salmonella Enteritidis e Minnesota e tratados com ácidos orgânicos. Pesquisa Veterinária Brasileira, 32(1), 27-36. doi: 10.1590/ S0100-736X2012000100006

Prestinaci, F., Pezzotti, P., \& Pantosti, A. (2015). Antimicrobial resistance: a global multifaceted phenomenon. Pathogens and Global Health, 109(7), 309-318. doi: 10.1179/2047773215Y.0000000 030 
Ramos, L. S. N., Lopes, J. B., Silva, S. M. M. S., Silva, F. E. S., \& Ribeiro, M. N. (2011). Desempenho e histomorfometria intestinal de frangos de corte de 1 a 21 dias de idade recebendo melhoradores de crescimento. Revista Brasileira de Zootecnia, 4O(8), 1738-1744. doi: 10.1590/ S1516-359820110008 00017

Ramos, O. H. P., \& Selistre-de-Araujo, H. S. (2006). Snake venom metalloproteases - structure and function of catalytic and disintegrin domains. Comparative Biochemistry and Physiology. Toxicology \& Pharmacology, 142(3-4), 328-346. doi: 10.1016/j.cbpc.2005.11.005

Ross, J. G., Christie, G., Halliday, W. G., \& Jones, R. M. (1977). Haematological and blood chemistry "comparison values" for clinical pathology in poultry. The Veterinary Record, 102(2), 29-31. doi: 10.1136/vr. 102.2.29

Santos, M. J. B., Ludke, M. C. M. M., Ludke, J. V., Torres, T. R., Lopes, L. S., \& Brito, M. S. (2013). Composição química e valores de energia metabolizável de ingredientes alternativos para frangos de corte. Ciência Animal Brasileira, 14(1), 32-40. doi: 10.5216/cab.v14i1.17697

Segrest, J. P., De Loof, H., Dohlman, J. G., Brouillette, C. G., \& Anantharamaiah, G. M. (1990). Amphipathic helix motif: classes and properties. Proteins, 8(2), 103-117. doi: 10.1002/prot.340080202

Silva, E. N., \& Duarte, A. (2002). Salmonella Enteritidis em aves: retrospectiva no Brasil. Revista Brasileira de Ciência Avícola, 4(2), 85-100. doi: 10.1590/S1516635X2002000200001

Soares, A. M., Andrião-Escarso, S. H., Bortoleto, R. K., Rodrigues-Simioni, L., Arni, R. K., Ward, R. J.,.. Giglio, J. R. (2001). Dissociation of enzymatic and pharmacological properties of piratoxins-I and -III, two myotoxic phospholipases A2 from Bothrops pirajai snake venom. Archives of Biochemistry and Biophysics, 387(2), 188196. doi: 10.1006/abbi.2000.2244

Soares, A. M., Guerra-Sá, R., Borja-Oliveira, C., Rodrigues, V. M., RodriguesSimioni, L., Rodrigues, V.,... Giglio, J. R. (2000). Structural and functional characterization of BnSP-7, a Lys49 myotoxic phospholipase A2 homologue from Bothrops neuwiedi pauloensis venom. Archives of Biochemistry and Biophysics, 378(2), 201-209. doi: 10.1006/ abbi.2000.1790

Talebi Mehrdar, M., Madani, R., Hajihosseini, R., \& Moradi Bidhendi, S. (2017). Antibacterial activity of isolated immunodominant proteins of Naja Naja (Oxiana) venom. Iranian Journal of Pharmaceutical Research, 16(1), 297-305. doi: 10.22092/ ari.2017

Uni, Z., Ganot, S., \& Sklan, D. (1998). Posthatch development of mucosal function in the broiler small intestine. Poultry Science, 77(1), 75-82. doi: 10.1093/ps/77.1.75

Valentin, E., \& Lambeau, G. (2000). Increasing molecular diversity of secreted phospholipases $A(2)$ and their receptors and binding proteins. Biochimica et Biophysica Acta, 1488(1-2), 59-70. doi: 10.1016/s 1388-1981(00)00110-4

Waldemarin, K. C. A., Beletti, M. E., \& Costa, L. F. (2004). Nuclear morphometry of neoplastic cells as a method for diagnosis of histiocytoma, mastocytoma and transmissible venereal tumor in dogs. Real-Time Imaging, London, 10(4), 197204. doi: 10.1016/j.rti.2004.05.003 
